\title{
Between Individual Decisions and Collegiate Deliberations: Deciding How To Decide, Influencing the Outcome
}

\author{
Entre Decisões Individuais e Deliberações Colegiadas: decidindo como \\ decidir, influenciando o resultado
}

\author{
José Mário Wanderley Gomes Neto ${ }^{1}$ \\ Flávia Danielle Santiago Lima² \\ Tassiana Moura de Oliveira ${ }^{34}$ \\ ${ }^{1}$ Universidade Católica de Pernambuco, PE, Brasil \\ ${ }^{2}$ Universidade de Pernambuco, PE, Brasil \\ ${ }^{3}$ Universidade Federal de Pernambuco, PE, Brasil \\ ${ }^{4}$ State University of New York, Albany, New York, USA
}

\begin{abstract}
How does the institutional design of the Brazilian Supreme Court (STF) interfere in the decision-making process of the conflicts that are submitted to it? STF's Justices, as individually responsible of each proceeding in progress, can strategically decide through available procedural resources what and when to bring them to trial individually or collectively. This article inserts itself in this debate to question the independence of its Justices before the other political actors, but also before (or against) their peers, considering the possibilities of interaction of strategic models to the Brazilian case, before the constitutional, legal and regimental rules that establish the performance of the members of the Court. The general hypothesis is that the normative design of the Court assures multiple options for magistrates in the conduct of judicial proceedings, promoting strategies aimed at maximizing the winning chances of their preferences, as well as reducing their respective decision costs.
\end{abstract}

Keywords: Brazilian Supreme Court. Judicialization of Politics. Judicial Behavior. Strategic Model.
Resumo: Como o desenho institucional do Supremo Tribunal Federal Brasileiro interfere no processo decisório dos conflitos que lhe são submetidos a julgamento? Os Ministros do STF, na qualidade de relatores dos processos em tramitação, por meio de recursos procedimentais disponíveis, podem decidir estrategicamente o que e quando levar a julgamento, individual ou coletivamente. O presente artigo insere-se neste debate para questionar a independência dos seus Ministros perante os demais atores políticos, mas também diante (ou contra) seus pares, cogitando-se as possibilidades de interação de modelos estratégicos ao caso brasileiro, diante das normas constitucionais, legais e regimentais que fixam a atuação dos membros do Tribunal. A hipótese geral é que o desenho normativo da corte assegura múltiplas opções aos magistrados na condução dos processos judiciais, promovendo estratégias voltadas a maximizar as chances vitoriosas de suas preferências, bem como reduzir os respectivos custos decisórios.

Palavras-chaves: Supremo Tribunal Federal. Judicialização da Política. Comportamento Judicial. Modelo Estratégico.

Recebido em: 22/02/2019

Revisado em: 11/03/2019

Aprovado em: 18/03/2019 


\section{Judicialization of Politics in Brazil: a Super-Court, 11 Supreme Justices}

Brazilian Supreme Court (STF) is considered a key element in the Brazilian institutional arrangement, because of the remarkable universe of subjects submitted to its appreciation and for its willingness to interfere in relevant causes of national political life. Under the light of the Court's main role, since the enactment of the Federal Constitution of 1988, a research agenda has been consolidated around the Court's activity (and omissions), with attention to institutional and behavioral factors that explain its functioning, in interaction with others political actors, among the procedures and decisions taken.

More recently, the internal dynamics established by the 11 Justices, in the exercise of the multiple powers of the "guardian of the Constitution" draw attention, in an attempt to understand the consequences of the institutional design of the Supreme Court for the conduct of procedures. In this universe, the individual manifestations of the members of the Court, possibly described as 11 decision-making islands, would be a consequence of the procedural instruments that allow the members, in a decentralized and individual way, to decide, signal and set an agenda, from the granting of injunctions, in an arrangement known as "ministocracy" (ARGUELHES; RIBEIRO, 2018). This immense individual power of each judge is usually seen through individual decisions, as pointed out by Falcão and Arguelhes (2017, p. 20-21), that in 2016, decisions with the greatest political-institutional impact came from individual acts, revealing strategic behavior in between the Justices, as such a power demonstration.

The present work intends to move forward in the debate to understand the increasing individual judicial action, from the description of the possibilities of a Rapporteur Justice to define in the scope of the STF the judicial body - Monocractic, Chamber or Plenary - to solve the dispute, having in this change an interesting instrument to interfere in the deliberation result. 
In order to do so, this work will analyze the STF's institutionalnormative model, its organization and the legal status of its Justices. Also, the work will bring the constitutional, legal and regulatory frameworks that assign the contours of the Justices' behavior, which is fundamental for understanding its high degree of independence. The qualitative analysis (case study) of the Habeas Corpus (HC) 152752 is used to identify how the Justices showcase their (strategic) preferences in accordance to the Court's procedural rules and practices. We question how independent the Justices are compared to other political actors, having STF's institutional design in the background, and also before (or against) their peers. To explain theoretically, we will use judicial behavior's explanatory models and will apply them to the Brazilian case, notably the strategic behavior verified in that case.

\section{Who Watches the Watchmen? The independence of the STF Justices}

The Federal Constitution of 1988, despite greatly strengthening the Judiciary, expanding its functions, maintained, in general, the historical rules of composition and choice of the Court's members. According to the article 101, the Court must be composed by eleven judges, called "Ministros" (in Portuguese), to be chosen among native Brazilian citizens, who are over 35 years of age and under 65 at the time of the investiture. Other requirements are: they must possess "outstanding legal knowledge" and "unblemished reputation" These criteria do not have normative guidelines for their measurement. The objective qualification - training and attention to ethical standards - is usually analyzed in the selection process. There are no normative guidelines for the second criteria.

The prevailing interpretation is that the applicant does not need to have a bachelor's degree in law, but historically only jurists are nominated. More recently, there has been a tendency to choose Justices who are distant from partisan or electoral political life, and have an exclusively legal career - especially lawyers and teachers (ALMEIDA, 
2015). Basically, one can point to two profiles: career magistrates and non-magistrates, with the recent predominance of the latter.

The recruitment factor, therefore, is the "legitimacy of nominations among all law professions, including lawyers, prosecutors, university professors and magistrates, especially among recent appointments" rather than previous experience in the judiciary (DA ROS, 2012). This new inclination has repercussions in the exercise of the activity inside the Court. Fabiana Luci de Oliveira (2012) affirms that the Justices' broader experience helped to build a Court which is more participative regarding State's decisions.

Although they don't have a limited term, the Justice's must retire at the age of 75 as well as all the political agents ${ }^{1}$ in Brazil. Therefore, a Justice could stay up to four decades working in the Court. However, especially if we look to the appointment of young jurists (outliers), the analysis of STF data shows that the average length of stay is relatively low. In the period between 1984 and 2014, for example, this length is of 9.82 years only (ALMEIDA, 2015).

The process of choosing and nominating, since the STF's inauguration, is reasonably simple: the nominees are appointed by the Executive Chief and approved (or not) by the Federal Senate (upper legislative chamber). According to the Brazilian Constitution (article 101, sole paragraph; article 84, XIV) and rules found in the Internal Regiment of the Federal Senate (article 101, I; article 288, II, d), the process is initiated by the presidential nomination, followed by a hearing (a public and televised session) lead by the Senate's "Constitution and Justice Commission". After that, the decision will be made by the Senate Plenary through a vote session, by absolute majority requirement for one's approval; if approved (which requires the positive vote of at least 41 of

\footnotetext{
${ }^{1}$ In 2015, the Brazilian National Congress approved a Constitutional Amendment (n. 88/2015), known as the "Bengal PEC", which changed the compulsory retirement age of public servants, including Supreme Court Justices from seventy (70) to seventy-five (75) years, thus preventing President Dilma Rousseff from appointing new Justices to the positions currently occupied by Justice Celso de Mello (69 years) and Justice Marco Aurélio (69 years).
} 
the 81 senators), the nomination ends with the presidential decree, and the last act is the possession before the STF's Plenary.

At that moment, the new Justice will have the institutional and functional guarantees given by the Constitution to members of the Judiciary, namely: (i) self-government (the Courts elect their leadership and draw up their internal regulations, not to mention that they organize the selection of new judges); (ii) competence to initiate laws to determine the general rules of the activity of members of the judiciary, including establishing the number of lower court judges, creating or terminating lower courts, and changing the judicial organization; (iii) financial management by presenting its budget proposal. At the same time, he receives magistrates' functional guarantees, which are: (i) vitality; (ii) immobility, meaning that a magistrate cannot be removed from his or her functional jurisdiction without their agreement; and, (iii) wage irreducibility (TOMIO, ROBL, 2013).

However, the relevant guarantees and functions are not accompanied by stronger instruments of accountability of their activity: STF's Justices are only subject to impeachment as a result of conviction for a crime of responsibility (Brazilian Federal Law n. 1.079/1950), as well as to limitations in their careers specified by the "Organic Law of the National Magistracy" (Lei Complementar n. 35/1979). The judicial structure and the guarantees of this institution would insulate the Justices of the STF - especially its President - regarding possible controls over their performance (LIMA; ANDRADE; OLIVEIRA, 2017).

The STF's Justices are not submitted to the National Council of Justice (CNJ), an exclusively administrative institution, which has powers to control the administrative, financial and disciplinary activities of the Judiciary branch. Considering that this Council was created by a Constitutional Amendment (EC n. 45/2004), the analysis of its compatibility to the "cláusula pétrea" - constitutional intangible clause - the separation of powers (article $60, \S 4, \mathrm{CRFB}$ ) - was taken to the STF by the Association of Brazilian Magistrates (AMB) ${ }^{2}$.

${ }^{2}$ In this regard, it should be noted that the Brazilian institutional design allows judicial review of constitutional amendments, so as to ensure the so-called immutable clauses 
. On that occasion, the Court ruled that the "CNJ has no jurisdiction over the Supreme Court and its Justices, which is the highest body of the national Judiciary to which it is subject." In addition, it was understood that the decisions of the Council are subject to the judicial control from the STF itself, according to the Brazilian constitution (103-B, $\S 4, \mathrm{CRFB})^{3}$ (LIMA et al., 2017).

As it was said before, there is the possibility of impeachment of a Justice. First, any Brazilian citizen could send a "denunciation" to the Senate and ask for his or her impeachment. However, the judgment only occurs if it is based on a crime of responsibility, under the terms of art. 52, II, of the Brazilian Constitution, resulting in the conviction of "loss of office, with eight years of incapacity to exercise public office, without prejudice to other applicable judicial sanctions". It is a crime of a legalpolitical nature, applicable to other political agents. The Justices would be judged by the Federal Senate, which, after an admissibility hearing by the Bureau of this institution, would follow up the rite under the leadership of the President of the STF. For the approval of the request, a two-thirds majority of the Senators is required.

The typified conducts are provided by Law n. 1.079/50 and they are: to amend, in any way, except by means of appeal, the decision or vote already rendered in session of the Court; to judge, when, by law, one is suspect in the case; to exercise political-partisan activity; to be patently indifferent in fulfilling the duties of the office; and to proceed in a way incompatible with the honor and dignity required by one's function.

The general rules and guidelines for the exercise of the judicial function are set by the Organic Law of the National Magistracy (LC n. 35/1979), which specifies all the prohibited practices.

provided by art.60, paragraph 4, of the Constitution. Thus, the jurisprudence of the STF admits, even, the suspension of the legislature's validity by injunction, in concentrated judicial review (LIMA, BEÇAK, 2016).

${ }^{3}$ As said Zaidan de Carvalho (2017) the representative framework of the STF Justices' impartiality discourse described from the decisions in the arguments of impediment and suspicion is highlighted by the deficiency of deliberative criteria adequate to express the visibility of the way in which the members of the court define the limits of its own jurisdiction when its impartiality is questioned. 
There was not, until the moment of finalization of this text (July/2018), a single judgment of a STF's Justice regarding a crime of responsibility. However, in recent years, because of the political upheaval, there has been an increase in the number of denunciations by citizens some of them with a great repercussion - but those requests did not go any further by the decision of the Federal Senate. ${ }^{4}$

\section{From a Normative Prediction to an Institutionalized Practice: "every Justice, a Supreme Court"}

The STF structure derives from the provision of articles 101 and later of the Brazilian Constitution, but rules of operation, as a corollary of the guarantee of organizational autonomy, are established by the Rules of Procedure of the Brazilian Supreme Court (Regimento Interno, or simply RISTF), approved by the Justices themselves, which distributes decision-making powers through the organs of the Court: Plenary of the 11 Justices), two Chambers formed by 5 Justices and specific attributions of the President, chosen by the peers for a 2-years mandate (article 3 of the RISTF).

The articles 9 to 11 establish functions for the Chambers, such as the adjudication of mandados de segurança and habeas corpus, certainly more complex than those assigned monocratically to the Justices. But the most relevant decisions are reserved to the Plenary, as is inferred from article 11 of the RISTF, e.g., the adjudication of concentrate judicial review ${ }^{5}$.

\footnotetext{
${ }^{4}$ Between 2016 and 2017, the 11 Brazilian Supreme Court (STF) justices were targeted for 20 impeachment requests - a figure that represents 80 percent of all 25 targeted to current court members, according to a report from the BBC. Available in: http://www.bbc. com/portuguese/brasil-41505548.

${ }^{5}$ As determined by Article 11 of the Rules of Procedure of the Brazilian Supreme Court (Regimento Interno), each Justice may decide when to submit a particular case to the Plenary in three situations: (1) when it considers a constitutional matter as yet undecided by the Plenary; (2) when proposing the prior review of the matter; (3) when any Justice proposes to review the jurisprudence of the Court in such cases. Note a wide margin of subjectivity in each of these situations.
} 
From this organizational framework, there are three formats of judgment in the Court, depending on the chosen procedural instrument: monocratic decisions, Chambers and Plenary. Even in the collegiate bodies - Chambers or Plenary - the enormous individual power of the STF Justices draws attention. This power is clearly related to the procedure institutional design before the Court. In fact, empirical research converges on one point: the prevalence of individual manifestations of Justices (especially rapporteurs), to the detriment of a collegial performance of the Court, characterized as a "ministocracy" (ARGUELHES; RIBEIRO, 2018). The 11 Justices, in this way, would act as 11 "islands" (FALCÃO, 2015), due to the high degree of independence that they have.

In this sense, Falcão and Arguelhes (2017) highlight the phenomenon of the fragmentation of decision-making process and the emptying of STF's collegiate bodies, by pointing out that in 2016 the most important judicial decisions (from the point of view of their political and institutional impact) came of monocratic judicial acts (constituted by the exercise of judicial review power by a single member of the court without immediate or later submission to their peers), revealing points of strategic behavior of the Justices in relation to their colleagues.

As a result, less than $1 \%$ of the cases received by the tribunal are brought to the Plenary for discussion among all 11 Justices (MOLHANO; ARGUELHES, 2013), and even after deliberation, any of the Justices have (at their disposal) formal and informal mechanisms to influence often for longs periods of time - in the court's decision.

Thus, it is reported that about $87 \%$ of the decisions that the court took between 1988 and 2011 were monocratic - decisions taken by a single Justice, although the vast majority of these cases refer to processes of low complexity. This high percentage is attributed to procedural problems or because they are in clear disagreement with the jurisprudence of the court (MOLHANO; ARGUELHES, 2013) ${ }^{6}$.

\footnotetext{
${ }^{6}$ Procedural issues are those cases in which there is flagrant failure to comply with mandatory precedents of the Court, formal defects resulting from poor compliance with the procedural rule or lack of admissibility of appeals (VERÍSSIMO, 2008).
} 
Even in the Chambers or the Plenary, as seen, stands out the immense individual power of the STF Justices. In order to understand such power, it is important to understand the procedural process before the Court, based on procedural rules. Once a complaint has been filed with the STF, it is distributed to a Rapporteur Justice by electronic lottery, on a first come, first served basis. However, considering that Justices receive thousands of actions each year ${ }^{7}$ and that the normative criteria for establishing the agenda (agenda-setting) are relatively open, there is so a high degree of discretion ${ }^{8}$.

The original primary function of the Rapporteur is to summarize the case: a brief description of litigants' arguments and the decisions previously made (when it comes by appeal), and, of course, give their reasoned opinion (vote) on the case, with the reasons for the constitutionality or unconstitutionality of the issue (SILVA, 2011).

Already in this first moment there is a character of significant impact for the deliberative process of the Court: only a copy of the report is distributed to the other Justices as they should prepare their individual votes before the session without knowing the Rapporteur's opinion. As Silva (2011) points out, the opinion of the judge most familiar with the case is "revealed" only in the collegiate session, when votes are read and - subsequently - published. This model of deliberation is seriatium, all these votes (although in the same sense) will be published individually. Hence, the Court's opinion on the case would be a sum of 11 votes (which, in a large number of cases, have already been drafted before the plenary discussion) and not a decision of the Court stemming from a strong discussion among Justices, which has repercussions on the integrity of the Court as a collegial institution (VIEIRA, 2009).

\footnotetext{
${ }^{7}$ According to data provided by the STF itself, in January 2016, 53,931 cases were awaiting judgment in this Court, an average of 4,903 cases, approximately, per Justice.

${ }^{8}$ According to the Civil Procedure Code (Law n. 13,105 / 2015), it has processing priority cases in appearing people over 60 years old and/or with serious illness (art. 1048). Already, the art. 145 of Rules of Procedure of the Brazilian Supreme Court (Regimento Interno) establishes the priority procedures for trial (e.g., habeas corpus, extradition requests, criminal cases conflicts of jurisdiction, controversies from the Supreme Electoral Tribunal and injunctions requests).
} 
For Virgílio Afonso da Silva, the seriatium model of opinion reading, when associated with certain procedural constraints in the Brazilian Supreme Court, may, in some cases, lead to an unequal participation in the judicial decision-making process (SILVA, 2011). In fact, the regimental norms offer several possibilities for a Justice to be able to influence the outcome of the deliberation, independently of the final decision. As a general rule, the formation of the agenda is responsibility of the President of the Supreme Court (Chief Justice), but all other Justices (as rapporteurs on the proceedings in process) can strategically decide what (and when) they choose to bring to trial, individually or collectively.

The Rapporteur, for example, can or cannot put the process on the agenda of collegiate bodies, imposing his decision-making judgment on other Justices. In some procedural matters, it is incumbent on him to analyze the preliminary injunction, whether or not to culminate in the provisional suspension of a norm considered unconstitutional, or to suspend the appointment of a former President of the Republic (Luiz Inácio Lula da Silva himself, in 2016) to a Ministry. In other way, Justices, if not convinced, can interrupt the plenary session and request a hearing in order to clarify points and better support their decisions (SILVA, 2011). In other words, a single Justice can influence the formation of the agenda, that is, the order in which the issues would be decided.

The temporal element is of the most important for the understanding of the power of the STF in the Brazilian political and juridical system. It is also said that the STF "would be a political tribunal not only because it agrees or disagrees with the Executive or Congress. But rather because it controls the time to agree or disagree" (FALCÃO, 2015). And in this decision-making process, the individual role of the Justices stands out from conducts such as (a) "avoiding the plenary" - "before the plenary can speak on a topic, their participation may be delayed by actions of the rapporteur, for long periods of time "; (b) "to house the plenary - even when the Justice takes the matter to the plenary, can create consummate facts that make it much more costly to disagree with the individual decision" and (c) "oppose the plenary" - with the use of "decision- 
making power to ignore or counteract the plenary demonstration." (FALCÃO; ARGUELHES, 2017).

In this interest to convince colleagues of their opinions, strategies similar to lawyers are pointed out, to "win at any cost", as not to divulge certain information (SILVA, 2011). And of course, to achieve certain results, in a conjugate of individual preferences, we have the formation of clusters $^{9}$, that is, the presence of groups that share the same position in a more constant way (OLIVEIRA, 2012).

Finally, individualisms would be displayed by the costs of writing individual vows - against excessive workload - even in situations of unanimous deliberations. This conduct is attributed, among other factors, to the prior drafting of the votes for simple reading in session, in addition to the proximity to the public hearings (SILVA, 2011). It is thus observed that the interpretation of an individualized court has strong seat in institutional practices, in which a single Justice can choose to act in name of her pairs or change the directions of the final deliberation.

\section{Deciding How to Decide, Influencing the Outcome: an analysis of the judicial strategies of the rapporteurs}

The construction of a judicial decision, especially collegial decisions, inherent to the courts, is not an easy task, since the institutional design of these judicial bodies - In their primary constitution - foresees and encourages collective participation in the resolution of a conflict that is submitted to it, now via resources, or via processes of their original competence.

\footnotetext{
${ }^{9}$ Fabiana Luci de Oliveira (2012) was able to identify - throughout the history - two groups: "the first one is composed by Justices named during the military regime and by all the Justices named by President Fernando Henrique Cardoso, that is to say, it is composed of the Justices Moreira Alves, Sydney Sanches, Octavio Gallotti, Maurício Corrêa, Nelson Jobim, Ellen Gracie and Gilmar Mendes. Then there is the second group, composed of three of the Justices nominated by Lula: Eros Grau, Ricardo Lewandowski and Carmen Lúcia".
} 
Such participation is carried out by the sum of the preferences of distinct and heterogeneous individuals in their thoughts and actions, which, depending on the incentives and characteristics of each case, can guide their behavior, aiming at maximizing their individual preferences, reducing costs (social, economic, political and legal) and to achieve the expectations of its peers, the legal community and even outside actors, e.g., public opinion, political parties or Parliament.

Obtaining a majority in a decision, however, is relatively easy compared to the problem of getting five or more Justices, endowed with intelligence, will power, and individuality to agree as a whole, on a vote written by one of them. The degree of difficulty increases due to the importance and complexity of the subjects presented in the case. A Justice who is determined to write his vote without any cession to the preferences of his colleagues is apt to discover that he is writing only for himself (MURPHY, 1964).

On the other hand, as mentioned earlier, in many situations and through multiple factors, ranging from the nature of the conflicts to the expectations of the requesting actors, the members of the courts (collective institutions by nature) also use institutional instruments to realize their individual preferences, eg the request for a hearing and monocratic decisions, despite the existence of other preferences, to influence the calculation inherent in the formation of a collegial trial. What, then, is the variation in decision options (between individual and collective decisions), as well as between collegiate bodies of the same court, operated through various procedural mechanisms?

At this point, there is a favorable environment for the application of a strategic model for the explanation of judicial choices: in its fundamental premise, magistrates would suffer constraints in their preferences, through the influence of other political actors, institutions outside the Court and internal institutions of the Court when it comes to taking decisions in the face of a dispute before them (EPSTEIN; KNIGHT, 1998).

Since the Court is a collegiate body that decides by majority rule, judges may have an institutional incentive to vote strategically and to influence who wins the case. Which litigant wins is important insofar as 
it affects the content of the Court's opinion, which is a precedent and law (CLARK et al., 2018, p. 6). In this sense, according to Epstein and Walker (2007), judges are strategic actors, insofar as they perceive that the ability to achieve their objectives depends on the consideration of the preferences of other relevant actors, their expectations and the institutional context in which come to exercise the jurisdictional activity.

Constraints of internal and external nature to the judicial body can generate institutional incentives for judges to behave in a strategic way, weighing the costs that they could bear because of the results of their decisions and responding positively or negatively to the expectations of the actors involved (MURPHY, 1964).

In this sense, Brenner and Whitmeyer (2009), analyzing the US Supreme Court, have identified that some rapporteurs, in certain situations, where there is a change in decision making cost (social and political), adopt different strategies aimed at attracting the votes of other members of the court, seeking to form temporary coalitions in favor of the opinions that reflect their preferences, in number that eventually is enough to achieve the result they want. In turn, Larsson et al. (2017) observed that judges who are members of the European Court of Justice strategically decide when or not to invoke precedent in the reasoning of their decisions (opinions), in order to obtain the adhesion of their peers.

Strategic calculations belong to a category of rational choice models in which researchers assume that results-oriented actors - Including judges - operate in a strategic or interdependent decision-making context. In this calculation: (a) social actors make choices in order to achieve certain outcomes; (b) social actors behave strategically in the sense that their choices depend on their expectations about the choices of other actors; and (c) these choices are structured by the institutional environment in which they are made (EPSTEIN; JACOBI, 2010).

Kagan et al. (2018) argue that courts (and their judges individually) use strategic timing and skillful forms of judgment to make it feasible to build judicial consensus and allow courts to go through turbulent times, emerging with new roles, powers and responsibilities in the face of conflict resolution. 
In specific situations and in the presence of incentives, judges would adopt defensive behaviors of their interests and preferences, in order to avoid these undesirable results, capable of exposing them to the expectations of their peers, political actors, public opinion and other institutions involved in the trial of that litigation. With respect to the subject of this work, two hypotheses derived from the strategic model provide a way to understand the research problem: aversion to divergence and aversion to reform.

In a situation of aversion to divergence, judges would use strategies available in the institutional designs of courts to avoid negative exposure arising from the minority position in which their proposal is situated, since a judge would not initiate a divergence unless he anticipates a benefit in diverging which would outweigh its costs (EPSTEIN; LANDES; POSNER, 2011). Thus, judges could, for example, strategically join majority votes in a certain case, not because they agree with it, but because publicly disagreeing could maximize the effects of the majority by drawing more attention to the issue (POSNER, 2008).

Another way emerges from the institutional design of our courts, as noted above, a wide range of possibilities in which the Justices act individually, from the individual concession of injunctions to the monocratic judgment of processes and resources, avoiding that the collegiate ones pronounce on the matter, effectively implementing a "loop" that allows Justices to carry out "individual judicial review", blocking political initiatives, even if they are largely in the majority" (ARGUELHES; RIBEIRO, 2018).

Already in aversion to reform, judges, who, for the most part, do not appreciate seeing their reformed decisions and consider such a situation a negative exposition (POSNER, 1993), tend to avoid conducts that would expose their individual preferences if there is a risk of reversibility: if the chances of their decisions being reviewed by their own colleagues, e.g., via internal appeals, the possibility of reversal are likely to influence judicial behavior (EPSTEIN; JACOBI, 2010). 
If a judge is averse to reform, for example, he would avoid exposing liberal theses or precedents if he is aware that the rest of the court (or a fractional organ), which have conservative inclinations.

Given the institutional environment of the Brazilian Supreme Court, whose characteristics were set out above, possible decision-making costs that could result from a monocratic decision could (for example) influence the Rapporteur to delay the decision, not to decide or to seek the construction of new majorities, as can be seen in the situations in which it is sought to submit the question to the Plenary, to the detriment of the original competence of the others fractional collegial organs (Chambers).

Table 1: Strategies available to the Rapporteurs by STF's institutional design

\begin{tabular}{|c|c|c|c|}
\hline Strategy & Monocratic & $\begin{array}{c}\text { Collegiate } \\
\text { (Chamber) }\end{array}$ & Collegiate (Plenary) \\
\hline Decision Costs & Individual & Shared & Shared \\
\hline Reform Risk & $\begin{array}{c}\text { Inconstant } \\
\text { (ability to appeal and } \\
\text { agenda-setting) }\end{array}$ & $\begin{array}{c}\text { None } \\
\text { (final decision) }\end{array}$ & $\begin{array}{c}\text { None } \\
\text { (final decision) }\end{array}$ \\
\hline Divergence Risk & $\begin{array}{c}\text { None } \\
\text { (individual decision) }\end{array}$ & $\begin{array}{c}\text { Inconstant } \\
\text { (depends on majority) }\end{array}$ & $\begin{array}{c}\text { Inconstant } \\
\text { (depends on majority) }\end{array}$ \\
\hline
\end{tabular}

Source: Prepared by the authors of this article

In this sense, the following paradigmatic case is observed: on April 5th, 2018, the Plenary of the Brazilian Supreme Court (STF) denied, by a narrow majority of votes (6x5), Habeas Corpus (HC) 152752, through which sought to prevent the provisional execution of the restriction of freedom penalty, upon confirmation, in the second instance of criminal conviction. The majority of the Justices accompanied the Rapporteur, Edson Fachin, in the sense of the absence of illegality, abusiveness or teratology (abnormality) in the decision of the Superior Court of Justice (STJ), which, by applying the case law of the STF, sentenced to prison after confirmation of the conviction at second instance.

A stylized strategy in that case drew attention because of its success in influencing the decision-making behavior of the Brazilian Supreme Court's Justices: criminal matter, initially without general repercussion, whose original jurisdiction would be of the 2nd Chamber was submitted 
to the Plenary, by decision of the Rapporteur Justice, in order to obtain the majority of votes sufficient to confirm the vote line proposed.

Note: There was a clear division of understandings between the two fractional organs of the Brazilian Supreme Court. While the 1st Chamber, composed of Alexandre de Moraes, Luís Roberto Barroso, Luiz Fux, Marco Aurélio and Rosa Weber, would be harder to grant habeas corpus and minded to sustain the condemnation; the second group, composed of Celso de Mello, Dias Toffoli, Edson Fachin, Gilmar Mendes, and Ricardo Lewandowski, showed themselves to be more bland and guarantor, contrary to the expansion of the state punitive power, whose example would be the hypothesis of compliance of the prison penalty after conviction at second instance.

After being dissident opinion (and preference loser) in other cases that dealt with the same matter (habeas corpus based on the unconstitutionality of the prison penalty sentence before the conviction had been passed), Justice Fachin decided, using procedural prerogatives available to all the Rapporteurs, to submit the HC 152752 to trial by the Plenary, which, consequently, brought to decision-making process all the preferences of the members of the 1st Chamber: enough number to confirm the view that the prison after conviction in the second instance should be maintained.

Was the conduct adopted by Justice Fachin a strategy to make his preferences winners on this issue?

Table 2: Strategies available to Justice Fachin in HC 152752 trial context

\begin{tabular}{|c|c|c|c|}
\hline Strategy & Monocratic & Collegiate (Chamber) & Collegiate (Plenary) \\
\hline Decision Costs & $\begin{array}{c}\text { High } \\
\text { (individual) }\end{array}$ & $\begin{array}{c}\text { Low } \\
\text { (shared) }\end{array}$ & $\begin{array}{c}\text { Low } \\
\text { (shared) }\end{array}$ \\
\hline Reform Risk & Low & Absent & Absent \\
\hline Divergence Risk & Absent & $\begin{array}{c}\text { High } \\
\text { (certain minority) }\end{array}$ & $\begin{array}{c}\text { Low } \\
\text { (uncertain majority) }\end{array}$ \\
\hline
\end{tabular}

Source: Prepared by the authors of this article

If the strategy of deciding monocratically is adopted, whether it is denying a preliminary injunction, or denying a proceeding (due to alleged 
procedural defects, such as the alleged non-habeas corpus in the concrete situation), or judging himself the merits of the case (imprisonment of a person by conviction on second instance), the Rapporteur, Justice Edson Fachin, would alone assume the high and undesirable (social and political) costs of maintaining the prison, as well as being subject to the risk of reform (through appeal) to be judged by the 2nd Chamber, which appeal's Rapporteur would be the same as of the habeas corpus, with full control of the agenda-setting.

On the other hand, if chosen the strategy of honoring the original competence of the 2 nd Chamber, there would be a sharing of decisionmaking costs with the other members of the fractional body, but there would be a high risk of divergence, based on previous monocratic decisions of other Justices and on body's own collegiate judgments, in which the opinion of Justice Fachin remained minority and dissident, exposed before his peers and the expectations of the other actors.

Finally, in the case under analysis, the strategy of bringing the habeas corpus to the judgment of the Plenary collegiate was effectively chosen, again sharing the decision costs, but in an environment of lower risk of divergence, since switched the certainty of the defeat by the 2 nd Chamber to the uncertainty of a narrow victory (lower risk of divergence) in a temporary new majority, composed of the sum of the members of the two groups and the Chief Justice Carmen Lúcia, in a tie vote.

This option proved to be successful, despite the tight $6 \times 5$ score, as it strategically managed to revert a high expected defeat result, without having to take on the enormous costs of a monocratic decision alone, as well as reducing final decision costs in a case where there was social and political repercussion. The procedural mechanisms available to the Rapporteurs were used intelligently, which allowed to include in the decision calculation (in the context of each case and the nature of the procedure under trial) what would be the institutional environment (judicial body), whether monocratic (Rapporteur), fractional collegiate (Chambers) or expanded collegiate (Plenary), with the best chances of resolving the conflict according to their preferences. 


\section{Conclusión}

Understanding the decisions taken by the Brazilian Supreme Court, whether in its collegiate or in individual positions, goes far beyond reading the legal grounds indicated in the written records or verbalized at the trial sessions.

Based on the procedural features provided by the Court's institutional design, Justices have sophisticated and intelligent strategies at their disposal to be chosen to maximize results favorable to their individual preferences or to reduce any harm to their interests, from reciprocal assignments (to persuade their peers) to choose the most favorable moment for agenda-setting.

Among these strategies, there is a unique possibility given to the Rapporteurs Justices: according to the moment, the socio-political context and the decision-making costs of each subject submitted to judicial review, they can perform a dynamic distribution of the natural judgment of the conflict between the fractional bodies of the court (monocratic judgment, Chambers and Plenary), in search for an institutional decisionmaking environment with a greater probability of a result that best represents the Justice's preferences regarding the controversial issue.

In the case under review (HC 152752), Justice Edson Fachin made a clever and strategic use of the procedural rules to find a scenario that would maximize the chances of victory of his preferences minimizing the risk of reform of the decision and publicly presenting himself as a dissenting majority vote.

By weighing up the risks and costs present in each of the three options available, he chose to bring the controversy over whether or not sustain the arrest warrant to the Court's Plenary, where he had a successful outcome (6 to 5), in counterpoint the options for judging monocratically or for bringing the conflict to the 2nd Chamber, where there would be greater decision-making costs and risks.

It should be noted, therefore, that the 1988's Constitution ensures a high degree of independence for the exercise of jurisdiction, with 
guarantees for judicial institutions, but also for all Brazilian judges individually. With regard to the Justices of the Supreme Court, these guarantees are strengthened, considering the strict possibilities of legal-political accountability. At the individual level, independence is also highlighted in front of the Court itself, under the terms of an Internal Regulation that admits various possibilities for conducting the proceedings by the Rapporteurs and other Justices.

This article sought to advance the debate about judicial decisionmaking processes and the consequent strategic behavior of the judging bodies, by qualitatively exploring this institutional possibility of dynamic change of the natural jurisdiction of each conflict, through which the Rapporteurs play with contexts, times, compositions and majorities, with the purpose of interfering in the final result, e.g., of an appeal, an habeas corpus or a constitutional process. However, in the next moments, it is suggested that empirical investigations (involving quantitative analysis of data) may provide even more in-depth answers about the decisionmaking dynamics, relating these strategic variables and the options of the Rapporteurs to choose between deciding monocratically, bringing conflicts to the Chambers or submit them to the Plenary.

\section{References}

ALMEIDA, F. Judicialização da política e composição dos tribunais superiores. Revista Parlamento e Sociedade, [S.l.], v. 3-4, p. 75-98, 2015.

ARGUELHES, D. W.; RIBEIRO, Leandro M. Ministrocracia: o Supremo Tribunal individual e o processo democrático brasileiro. Novos Estudos CEBRAP, [S.l.], v. 37-1, p. 13-32, 2018.

BRENNER, S.; WHITMEYER, J. M. Strategy on the United States Supreme Court. Cambridge University Press, 2009.

CARVALHO, A. D. Z. Imagens da imparcialidade: entre o discurso constitucional e a prática judicial. São Paulo: Almedina, 2017. 
CLARK, T.; MONTAGNES, P.; SPENKUCH, J. L. Politics From the Bench? Ideology and Strategic Voting in the US Supreme Court. CESifo Working Paper, [S.l.], n. 7.264, 2018.

EPSTEIN, L.; KNIGHT, J. The choices justices make. Washington, D.C.: Congressional Quarterly, 1998.

EPSTEIN, L.; WALKER, T. G. Constitutional Law for a Changing America: Institutional Powers and Constraints. Washington, D.C.: Congressional Quarterly Press, 2007.

EPSTEIN, L.; JACOBI, T. The strategic analysis of judicial decisions. Annual Review of Law and Social Science, [S.l.], v. 6, p. 341-358, 2010 .

EPSTEIN, L.; LANDES, W. M.; POSNER, R. A. Why (and when) judges dissent: A theoretical and empirical analysis. Journal of Legal Analysis, [S.l.], v. 3, n. 1, p. 101-137, 2011.

FALCÃO, J. O Supremo: compreenda o poder, as razões e as consequências das decisões da mais alta Corte do Judiciário no Brasil. Rio de Janeiro, Edições de Janeiro, Fundação Getúlio Vargas, 2015.

FALCÃO, J.; ARGUELHES, D. Onze Supremos: todos contra o Plenário. In: FALCÃO, J.; ARGUELHES, D. W.; RECONDO, F. (ed.). Onze Supremos: o Supremo em 2016. Rio de Janeiro, Fundação Getúlio Vargas, 2017. p. 20-28.

FALCÃO, J.; HARTMANN, I. A., CHAVES, V. P. Relatório Supremo em Números: o Supremo e o tempo. Rio de Janeiro: Escola de Direito do Rio de Janeiro da Fundação Getúlio Vargas, 2014.

KAGAN, R. A., KAPISZEWSKI, D., \& SILVERSTEIN, G. New judicial roles in governance. Comparative Judicial Review. Edward Elgar Publishing, 2018.

LANDES, W. M.; POSNER, R. A. Rational judicial behavior: a statistical study. Journal of Legal Analysis, [S.l.], v. 1, n. 2, p. 775-831, 2009. 
LARSSON, O. et al. Speaking law to power: the strategic use of precedent of the court of justice of the European Union. Comparative Political Studies, [S.l.], v. 50, n. 7, p.79-907, 2017.

LIMA, F. D. S.; ANDRADE, L. D.; OLIVEIRA, T. M. Emperor or President? Understanding the (almost) unlimited power of the Brazilian Supreme Court's President. Revista Brasileira de Direito, [S.l.], v. 13, p. 161-176, 2017.

LIMA, J. N.; BEÇAK, R. Emenda constitucional e constitucionalismo político: a potencial moderação das críticas ao controle judicial de constitucionalidade. Conpedi Law Review, [S.l.], v. 2, n. 4, p. 275-296, 2016.

MURPHY, W. Elements of judicial strategy. Chicago: University of Chicago Press, 1964.

OLIVEIRA, F. L. Processo Decisório no Supremo Tribunal Federal: coalizões e "panelinhas". Revista de Sociologia e Política, Curitiba, v. 20, n. 44, p. 139-153, 2012.

POSNER, R. A. What do judges and justices maximize? The same thing everybody else does. Supreme Court Economic Review, [S.l.], v. 3, p. 1-41, 1993.

POSNER, R. A. How judges think. Cambridge, Harvard University Press, 2008.

SILVA, V. A. Deciding without deliberating. I•CON, [S.l.], v. 11, n. 3, p. 557-584, 2011.

TOMIO, F. R. L.; ROBL FILHO, I. N. Accountability e independência judiciais: uma análise da competência do Conselho Nacional de Justiça (CNJ). Revista de Sociologia e Política, [S.l.], v. 21, n. 45, p. 29-46, 2013. 
José Mário Wanderley Gomes Neto é Mestre em Direito e Doutor em Ciência Política pela Universidade Federal de Pernambuco. Professor na Universidade Católica de Pernambuco e no Centro Universitário CESMAC.

E-mail: josemwgomes@gmail.com

Endereço profissional: Rua do Príncipe, n. 526, Boa Vista, Recife, PE, Brasil. CEP: 50050-900.

Flávia Danielle Santiago Lima é Mestra e Doutora em Direito pela Universidade Federal de Pernambuco. Professora na Universidade de Pernambuco (UPE) e na Faculdade Damas da Instrução Cristã (FADIC).

E-mail: flavia-santiago@uol.com.br

Endereço profissional: Av. Sport Clube do Recife, n. 252, Madalena, Recife, PE, Brasil. CEP: 50750-500.

Tassiana Moura de Oliveira é Mestra pela Universidade Católica de Pernambuco. Doutoranda pela Universidade Federal de Pernambuco. Visiting researcher SUNY at Albany. Bolsista Capes*.

E-mail: tassioliveira@gmail.com

Endereço profissional: 1400, Washington Ave, Albany, NY 12222, EUA.

*This study was financed in part by the Coordenação de Aperfeiçoamento de Pessoal de Nível Superior - Brasil (CAPES) - Finance Code 001. 